\title{
JUURNAL.RU
}

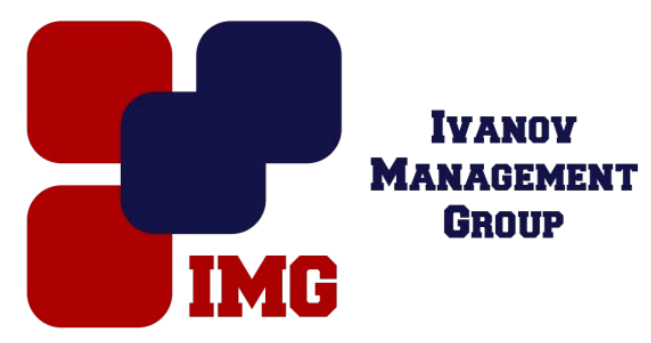

Миронов В.В., Сагандыков С.3., Простынюк Т. В. Омский государственный аграрный университет имени П.А. Столыпина Омск, Россия

doi: 10.18411/lj-31-10-2016-1-08

idsp 000001:lj-31-10-2016-1-08

\section{Экологическая безопасность при реконструкции на примере Карапузского магистрального канала в Убинском районе Новосибирской области}

\section{Аннотация}

В статье затрагивается тема безопасности экологии при реконструкции участка магистрального канала. Для предотвращения негативных последствий необходимо разрабатывать мероприятия для борьбы с ухудшением состояния экологии во время реконструкции, так как период реконструкции линейных объектов представляет серьезную угрозу для окружающей среды.

Ключевые слова: экологическая безопасность, реконструкция, магистральный канал, линейный объект, гидротехническое сооружение.

Реконструкция линейных объектов - изменение параметров линейных объектов или их участков (частей), которое влечет за собой изменение класса, категории и (или) первоначально установленных показателей функционирования таких объектов (мощности, грузоподъемности и других) или при котором требуется изменение границ полос отвода и (или) охранных зон таких объектов [4].

Реконструкция участка Карапузского магистрального канала предусматривает выполнение следующих видов работ:

1) Удаление древесно-кустарниковой растительности в существующем русле канала; 
2) Очистка поперечного сечения канала от наносов для пропуска паводковых вод;

3) Работы по восстановлению существующих трубчатых переездов.

Карапузский магистральный канал - существующий мелиоративный канал, который берет свое начало в оз. Малое Убинское и имеет протяженность 37,6 км. Через это расстояние русло канала сливается с руслом реки Карапуз.

В административном отношении территория канала расположена в Убинском районе, в 250-и километрах северо-западнее г. Новосибирска, и проходит от села Новый Карапуз до села Убинское.

Реконструкция магистрального канала предусматривает прохождение трассы по существующему руслу канала. Начало участка реконструкции ПК00+00, конец - ПК29+20. Ось канала совпадает с осью существующего сооружения.

Карапузский магистральный канал, как искусственное сооружение, существует очень давно, его трасса и полоса отвода остаются без изменений, дополнительного отвода земель при производстве работ по реконструкции не требуется. Воздействие канала на условия землепользования - положительное, так как понижается уровень грунтовых вод на прилегающей территории, снижается ее заболачиваемость. Извлекаемый грунт при расчистке используется для устройства насыпи в нулевых отметках эксплуатационных дорог. Нарушение рельефа не происходит, так как канал постоянно находится в тех же габаритах, что и изначально при проектировании.

Так как планируемые работы будут выполняться в русловой части Карапузского магистрального канала, а также в пределах его водоохранной зоны, то необходимо предусмотреть меры, позволяющие предупредить и устранить загрязнение водного объекта.

В качестве таких мер предусматривается [1]:

1) Строгое соблюдение производства работ, в том числе проезд строительной и дорожной техники в пределах границы полосы отвода;

2) Соблюдение технологии производства работ, с исключением не предусмотренных проектом работ;

3) Использование техники, прошедшей техосмотр, профилактические мероприятия и находящейся в исправном состоянии; 
4) Запрет работ в период нереста рыбы;

5) Расположение изымаемого грунта за пределами прибрежной защитной полосы канала (на расстоянии более 50 м от уреза воды);

6) Проезд и стоянка автотранспорта в границах водоохранной зоны водного объекта выполняется только по существующей эксплуатационной дороге, проходящей по левому берегу канала;

7) Проезд в водоохранной зоне водного объекта вне существующих проездов разрешен только специальным транспортным средствам;

8) После завершения реконструкции на территории объекта убирается строительный мусор, выполняются планировочные работы;

9) Проведение технической и биологической рекультивации нарушенных земель;

10) Проведение производственного экологического контроля при выполнении строительных работ;

11)Проведение мероприятий по компенсации нанесенного ущерба рыбным запасам - 1 раз в год в течение всего периода выполнения работ;

К мероприятиям по охране атмосферного воздуха от загрязнения на период реконструкции канала относятся [3]:

1) снижение времени работы строительной техники на холостом ходу до минимально необходимого по технологическому процессу;

2) использование при строительстве исправной техники, которая имеет свидетельства о прохождении технического осмотра. Не допускается ремонт и техническое обслуживание строительной техники на площадке строительства;

3) правильная эксплуатация двигателей техники, своевременная регулировка систем подачи и ввода топлива, что позволит обеспечить более полное сгорание топлива, снизить его расход, уменьшить выброс в атмосферу токсичных веществ и отработанных газов;

4) производство строительно-монтажных работ, движение машин и механизмов, складирование и хранение материалов вне полосы отвода и в местах, не предусмотренных проектом, запрещается; 
5) при наличии большого количества пыли осуществляется пылеподавление методом орошения (смачивание поверхности водой).

Реконструкция канала является одним из основных мероприятий по защите недр от подтопления. В результате реализации реконструкции не будет создано затопленных и подтопленных земель и повышения уровня грунтовых вод.

Для обеспечения необходимой охраны земель и подземных вод при реконструкции объекта предусмотрено [2]:

1) работы производятся строго в границах отведенной под строительство территории, не допуская сверхнормативного изъятия дополнительных площадей, связанного с нерациональной организацией строительного потока;

2) поверхностный слой земли стройплощадки и съездов предварительно срезается, а после завершения работ возвращается на прежнее место в ходе рекультивации;

3) для снижения эрозии почвы стройплощадка покрывается щебеночным покрытием толщиной 15 см.

При производстве работ воздействие на окружающую среду можно отнести к категории кратковременного воздействия, рассредоточенного на значительной длине.

К организационно-техническим мероприятиям, направленным на защиту от негативного воздействия на животный и растительный мир можно отнести:

1) перед началом строительных работ необходимо ознакомить рабочий персонал с видами животных, занесенных в Красную книгу, ареал распространения которых попадает в зону строительства;

2) в случае обнаружения гнезд птиц, занесенных в Красную книгу, необходимо обеспечить их локальную охрану;

3) запрещается несанкционированный отлов птиц и разорение гнезд;

4) в случае обнаружения «краснокнижных» растений необходимо обеспечить их пересадку за пределы строительной площадки, на участки со схожими условиями;

5) производство строительно-монтажных работ должно быть строго ограничено территорией, предоставляемой под строительство; 
6) перемещение строительной техники допускать только в пределах специально отведенных временных проездов;

7) обеспечение снижения до минимальных значений уровня шума;

8) при проведении работ максимально сохранять среду естественного обитания животных.

Принятые мероприятия обеспечат экологическую безопасность при реконструкции Карапузского магистрального канала. 


\section{Литература}

1. Водный кодекс Российской Федерации от 03.06.2006 N 74-Ф3 (ред. от 28.11.2015) (с изм. и доп., вступ. в силу с 01.01.2016);

2. Закон РФ от 21.02.1992 N 2395-1 (ред. от 13.07.2015) "О недрах" (с изм. и доп., вступ. в силу с 01.01.2016);

3. Федеральный закон от 04.05.1999 N 96-Ф3 (ред. от 13.07.2015) "Об охране атмосферного воздуха";

4. Федеральный закон от 18 июля 2011 г. N 215-Ф3 "О внесении изменений в Градостроительный кодекс Российской Федерации и отдельные законодательные акты Российской Федерации". 